\title{
A MISSIONAL STUDY OF THE USE OF SOCIAL MEDIA (FACEBOOK) BY SOME GHANAIAN PENTECOSTAL PASTORS
}

\begin{abstract}
Author:
DrP. White ${ }^{1}$

F. Tella ${ }^{2}$
\end{abstract}

M. D. $\mathrm{Ampofo}^{3}$

\section{Affiliation:}

1Department of Science of Religion and Missiology, Faculty of Theology, University of Pretoria, South Africa

${ }^{2}$ Department of Communication Studies, Christian Service University College, Kumasi Ghana

${ }^{3}$ Department of Theology, Christian Service University College, Kumasi - Ghana

Correspondence to: DrP. White

Email:

pastor_white@hotmail.com

\section{Correspondence to:}

F Tella

Email:

ftella@csuc.edu.gh

\section{Correspondence to:}

M.D. Ampofo

Email:

mishael.ampofo@gmail.com

Dates:

31 Oct 2016

How to cite this article: White, P., Tella, F. \& Ampofo, M.D., 2016. "A missional study of the use of social media (Facebook) by some Ghanaian Pentecostal Pastors". KOERS - Bulletin for Christian Scholarship, 81(2). Available at: http://dx.doi.org/10.19108/ koers.81.2.2250

\section{Copyright:}

(c) 2016. The Author(s). Published under the Creative Commons Atribution License.
Social media as a new phenomenon has become a tool used by many televangelists and pastors all over the world. It is against this background that this research sought to explore the Facebook activities of some Ghanaian Pentecostal pastors from a missional perspective. The article deals with the concept of social media, Facebook and its potential for mission purposes, the Facebook phenomenon among Ghanaians and how Ghanaian Pentecostal Pastors are using Facebook for missional purposes, as well as some of concerns on the negative uses of social media. The study revealed that Ghanaian pastors are followed by people from different religious and societal backgrounds. It has also offered the pastors and their congregations the opportunity to form relationships with a wide and diverse range of people without being bound by geographical space.

Keyword: Mission, Social Media, Facebook, Pentecostalism, Ghana, Social Media and Mission, Social Media and Evangelism.

Sosiale media as nuwe fenomeen het ' $\mathrm{n}$ instrument geword wat deur meeste TV-evangeliste en pastore regoor die wêreld gebruik word. Dit is teen hierdie agtergrond dat die Facebookaktiwiteite van sommige Ghanese Pentekostale pastore vanuit ' $\mathrm{n}$ missionale perspektief ondersoek word. In hierdie artikel word die volgende ondersoek: Die konsepte van sosiale media en Facebook, veral dan in terme van hulle potensiaal vir missionale doeleindes; die Facebookfenomeen, spesifiek onder die Ghanese; en die wyse waarop Ghanese Pentekostale pastore van Facebook gebruik maak vir missionale doeleindes. Die navorsing bevind dat Ghanese pastore deur mense van verskillende godsdienstige en sosiale agtergronde op sosiale media gevolg word. Dit bied aan pastore en hulle geloofsgemeenskappe die geleentheid om verhoudings met ' $n$ wye verskeidenheid mense te ontwikkel, sonder om deur die grense van geografiese gesitueerdheid beperk te word.

Sleutelwoorde: Sending, Sosiale media, Facebook, Pentekostalisme, Ghana, Sosiale media en sending, Sosiale media en evangelisasie. 


\section{INTRODUCTION}

Over the years, technology has been used as a medium for spreading the gospel from as far back as New Testament times. According to Justin Wise, the ink and scroll used by the Apostle Paul and others to propagate the gospel were considered cutting-edge technologies of their time (Wise 2014). During the Protestant Reformation, Martin Luther, using the cutting-edge technology of his day, the printing press, produced and distributed the 'Luther Bible' (Wise 2014:14). He believed that the bottom line of the gospel was for everyone to have unfettered access to God, not only to be able to plead for the forgiveness of sins but most importantly, for an intimate personal relationship with God. In a world full of technology, both electronic and print media have been used as tools for the preaching of the gospel by Pastors, Evangelists, Teachers of the gospel and Missionaries (White \& Niemandt 2015:255-259).

In contemporary times, social media have introduced a new reality in which each individual can create a threshold that works for him or her and move it as and when required. It gives one the opportunity to connect or communicate with hundreds of thousands of people (Nadella 2013:2). This assertion is true especially of the younger generation. Ghanaians, just like many people with access to the Internet, cannot seem to get enough of social media platforms such as Facebook, WhatsApp, Viber, Chat-on, BB, Line, Instagram, Twitter and many others. A study of the growth and usage of the Internet in Ghana shows that $33 \%$ of Ghanaians make use of online communication always, $25 \%$ make use of it frequently, with $30 \%$ use it occasionally. This, therefore, suggests that Internet usage has become part of the Ghanaian socio-cultural environment (Kasule 2013). This is what Sweet termed the ‘Googlers generation' (2012:3).

Niemandt defines social media as a form of self-directed mass communication that allows people to communicate with each other without going through the channels set up by the institutions of society for socialised communication (2013:30), encompassing a broad range of activities, platforms, and technologies all with a common theme: the ability to rapidly publish on the Web and to communicate with your audience (Brown 2001:16). According to Niemandt, social media play a very important role in the life of the church and the enculturation of the gospel (2013:37). The natural advantage of the use of social media is that they are fast, furious, and infectious (this is interestingly reflected in the use of the term "going viral" when referring to an item that spins out of control). It is an all-inclusive, non-restrictive, non-hierarchical and non-pretentious way of spreading the gospel (2012:187,190).

In the light of the use of social media for the missio Dei, scholars such as Peter White (White 2014:222), Frances Benyah (2015:5), Susan Codone (2014:3) have highlighted the missional use of social media and made recommendations for further research in this area by other scholars. White and Brenyah specifically recommended that future studies should focus on Ghanaian Pentecostal churches. This article therefore serves as a response to the recommendation from the scholars named above. The article specifically addresses an aspect of White and Benya's recommendation. The article discusses the use of social media for Christian evangelism with a focus on Facebook activities as engaged in by some Ghanaian Pentecostal Pastors and the influence of these activities on evangelism. The article has four main divisions -An overview of the notion of 'cyber church', the concept of social media; the Facebook medium and its potential for mission purposes; and the Facebook usage phenomenon among Ghanaians and Ghanaian Pastors.

\section{METHODOLOGY}

Content analysis and literature study constituted the datacollection methodology used for the study. Neuendorf describes content analysis as 'the primary message-centered methodology' (2002:27). Content analysis focuses on the characteristics of language as communication with attention to the content or contextual meaning of the text. The text might be verbal, in print, or in an electronic format, interviews, focus groups, observations, or print media such as articles, books, or manuals (Kondracki \& Wellman 2002).

According to Downe-Wamboldt, the objectives of content analysis are as follows: To describe substance characteristics of message content, to describe form characteristics of message content, to make inferences to producers of content, to make inferences to audiences of content and to predict the effects of content on audiences (Downe-Wamboldt 1992:314). Given these purposes of content analysis as suggested by Downe-Wamboldt, this article used the Facebook activities of some Ghanaian Pentecostal Pastors as a case study. The study was carried out between May and December 2015 by assessing the Facebook activities of some selected Ghanaian Pentecostal Pastors. The study also explored how these pastors use Facebook and its missional effect. The views of some individuals in the Kumasi Metropolis who patronise or are Facebook followers of the Pastors who were being studied were also considered and integrated into some of the sub-headings.

\section{OVERVIEW OF CYBER CHURCHES}

Though our study is aimed at investigating the Facebook activities of some Ghanaian Pentecostal Pastors, we have found it very important to discuss the 'cyber churches' phenomenon which is being used by some churches in developed countries. We are of the view that this overview will serve as a base for other scholars to do further research in this area as far as Pentecostalism in Ghana is concerned. Churches such as the Lighthouse Chapel International, the International Central Gospel Church, the Church of Pentecost and the Christ Apostolic Church International are gradually making use of the 'cyber church' phenomenon as an approach that is very constructive when dealing with missional purposes.

These technological developments are undoubtedly influencing the context of church congregations. According to Campbell:

The theoretical concept of networked religion, besides speaking to the form of spirituality that emerges out of online networked negotiations with traditional religion, shows how current religious narratives, practices, and structures are able to 
become increasingly flexible, transitional, and transnational as they are lived out both online and in an information- and technology-driven society. It helps explain the ways in which networked society creates new borderlands of interactions between the online and offline worlds, between the digital and embodied (Campbell 2011:85).

Campbell's view suggests that the Internet phenomenon is firmly integrated into religion. Research shows that most religions, including Christianity, are taking advantage of the Internet for information dissemination, identity, and evangelisation (Asamoah-Gyadu 2007, Baab 2008, Frobish 2002). Sturgill's study of the websites of Southern Baptist churches has established that a significant number of the churches studied have used their websites for promotional purposes or 'attracting visitors' than for relational objectives such as evangelisation. The contents on these websites included worship times, church addresses and weekly meetings, among others. In his view the websites of the churches studies were structured to be information dissemination tools rather than extending the evangelisation course (Sturgill 2004:164-176). Other studies have established that the use of websites facilitates two-way communication as some websites allow online discussions which create opportunities for members to share religious experiences online (Horsfall 2002:153-162).

The Internet has enabled practitioners of religions such as Christianity to make use of new ways of exploring the Christian faith and Christians are now able to chat and exchange information online on a variety of faith-related issues. A number of religious activities exist online and they include 'Online Worship', 'Online Recruitment and Missionary Activity' and 'Online Community' (Campbell 2010:19-25).

Online worship, also referred to as 'cyber churches', involves online environments structured along the lines of a conventional church. However, the distinction between a cyber church and a conventional church is that a cyber church exists only as a website. A cyber church makes available online resources such as audio/video sermons, texts and bulletinboard services to members. Members are able to post prayer requests and spiritual questions on the website platform (Pew Internet \& American Life Project 2000:10, 19).

These online communities are created mostly by church groups and sometimes by individuals to facilitate interaction with believers and members who are separated by geography. According to Campbell, online groups congregate around issues of faith and spirituality. Even though the cyber church has its own challenges, it has, however, enabled many churches to connect, interact and share the gospel with their members and other people. It has also helped some people who by the nature of their context or national constitution have lacked the open space for practising the Christian faith in order to better understand Christianity and also interact with other believers.

\section{THE CONCEPT OF SOCIAL MEDIA}

The emergence of social media has changed the face of communication all over the world. The entire social media concept is built on what is known as 'Web 2.0'. According to Constantinides and Fountain:

Web 2.0 is a collection of open-source, interactive and user-controlled online applications expanding the experiences, knowledge and market power of the users as participants in business and social processes. Web 2.0 applications support the creation of informal users' networks facilitating the flow of ideas and knowledge by allowing the efficient generation, dissemination, sharing and editing of informational content (2007:232-233).

Before the introduction of Web 2.0, Internet communication was mediated through 'Web 1.0'. Web 1.0 refers to the first stage in the World Wide Web, which was entirely made up of Web pages connected by hyperlinks. Features for Web 1.0 gave a little space for a social platform for communication purposes. The development of 'Web 2.0' shifted and expanded communication possibilities on the Internet to allow users the ability to send pictures, videos, and other content to as many people at once and this is what is also known as social media (Constantinides \& Fountain 2007:232). Social media are Web-based tools for communication that allow users to share content such as photos, videos, and link to resources. It takes on forms such as magazines, Internet forums, weblogs, social blogs, micro-blogging, wikis, podcasts, photographs or pictures, video, rating and social bookmarking (Baruah 2012:1-3). All social media platforms have the following fundamental characteristics: participation, conversationality, connectedness, community and openness (Mayfield 2008:5). The social media in this regard connect people to make possible diverse forms of communication with little or no restriction on individual views or opinions.

In view of this background on the concept of social media, it will not be far-fetched to assert that just as social media have been adopted by businesses and organisations, churches are increasingly employing social media platforms to engage with members and non-members of their congregations.

\section{SOCIAL MEDIA AND EVANGELISM}

Social media use by individuals and organisations and its popularity make it imperative for the church to also take advantage of this phenomenon to spread the Gospel of Jesus Christ (Wise 2014:26-27). In writing the foreword of Meredith Gould's book 'The Social Media Gospel: Sharing the good news in a new way', Hansen submits that the social media analogically serve as a stethoscope, magnifying one's ability to listen to your congregation and community, and a megaphone, magnifying the individual's ability to proclaim God's word to your community (2013:X). The primary purpose of using social media is to establish and maintain relationships; to connect with and stay connected with members of the congregation (Vosko 2011:91). According to Asamoah-Gyadu, the use of 
social media as a tool for evangelism could offer people the opportunity to be born again without being physically present at the location of a religious service (2007:232-233). It is a tool for interaction and connection, that opens doors and opportunities to engage with people who rarely, if ever, step foot in a church building. This approach is in other words called 'Social Ecclesia' (Social Ecclesia, 2014).

Waldschmidt asserts that some Christian leaders are of the view that the use of social media is a waste of time and it is (only) for young people (2014:6). In a similar vein, Jerod Clark states that:

While there are still plenty of churches debating whether or not they should use Facebook, 800 million people are already there-including people from your church... And if you decide to ignore Facebook, you're missing out on a ministry opportunity. Facebook takes time and it may not be your favorite thing in the world, but it is a valuable tool for communicating with your congregation and reaching out to their friends (2012:3).

With reference to Clark's submission it is clear that if the gospel should be preached to all people then social media cannot be eliminated or even just ignored. In Vosko's view, there are people who go to the community of social media in search of a new spiritual affiliation and the church must take advantage of that to enrol such people in the Kingdom of God (Vosko 2011:91).

Social media's features of connectedness, interactivity and being community-driven have proved useful to churches and pastors. Campbell asserts that online platforms such as social media supplement a user's involvement with the local church (2007:267).

Wellman and Haythornthwaite (2012) posit that the argument that online engagements by churches can affect face-to-face interaction is weak as studies have established that individuals who use social media can also increase their levels of face-toface communication in offline settings such as in the local church. Interaction on social media on Christian related issues has been found to strengthen and affirm religious activities and the authority of the church (Knowles 2013:135). Hutchings' study on Christian chatrooms established that a pastor's authority is not compromised online but rather strengthened as a result of spiritual support initiatives such as exhortation and encouragement offered to users (2011:1120).

The social media space is seen by the current younger generation of Christians as part of their everyday life and they are merely extending their religious meaning and activity into this environment (Helland 2005:9-12). The same is the case for the current generation of Christians in Ghana.

\section{GHANAIANS AND FACEBOOK}

Ghana's Internet penetration stands at $19.6 \%$ of the Ghanaian population - there are over five million people connected to the Internet in Ghana (Internet World Statistics 2015). This Internet audience is quite significant for targeting the Christian message in a country that has 71.2 per cent of its population identifying themselves as Christians (Ghana Statistical Service 2010:1, 6, 40).

The Internet World Statistic Report (2015) indicates that as of November 30, 2015, Ghanaian subscribers on Facebook were about 2,900,000 people, representing $1.6 \%$ of the population. Among the mobile Internet users in 2015, Facebook was ranked the most used social media platform in Ghana with $94.89 \%$, followed by Twitter (3.97\%), Pinterest (0.62\%), Google+ (0.18\%) and other social media platforms holding $0.34 \%$ (Ghana Social Media Usage Statistics Using Mobile 2015). Furthermore, Facebook was also ranked first with about 90.99\% among Ghanaian desktop computer users with Internet access. Twitter ranks second with $4.39 \%$, followed by Pinterest $1.46 \%$, Tumblr $1.11 \%$ and the remaining social media platforms holding 2.05\% (Desktop social network usage statistics in Ghana 2015).

The statistics give clear evidence that a high proportion of Ghanaians are Facebook subscribers. This also implies that Christians and ministers of the gospel in Ghana should not under-estimate the power of social media but rather consider it among the tools for evangelism and one of the means to participate in the missio Dei.

\section{GHANAIAN PASTORS AND FACEBOOK}

The advent of social media and for that matter Facebook, has not only benefited the secular world but also the church. It is now one of the tools the church can use for fulfilling the Great Commission.

Statistics regarding the use of Facebook by Ghanaian pastors indicates that in the months of July through to October 2015, Pastor Mensa Otabil's (the General overseer of the International Central Gospel Church) Facebook page was the fastest-growing page in Ghana, with about 149 users every day, 8,516 weekly and 28,607 in a month (Socialbakers 2015). Among the top 30 Facebook users in Ghana, as of August 19, 2015, Ghanaian pastors such as Pastor Mensa Otabil comes ninth (9th) with 902,209 followers, Bishop Dag Heward-Mills in the tenth (10th) position, with 742,739 followers. Archbishop Nicolas Duncan-Williams was twelfth (12th) on the list with 673,807 followers and Pastor Richard C. Witcomb in the twenty-second (22nd) position with 422, 017 followers (Socialbakers 2015).

From the statistics above, among the top thirty (30) Facebook users in Ghana, Charismatic Churches had four of their leading pastors represented. This demonstrates how Facebook has given these pastors and their churches another avenue to communicate with a broader number of people and spread the gospel and discipled their followers through the 'e-platform'. Social media ministry and for that matter Facebook ministry have brought about what could be called 'church without walls'.

By engagement with some of the followers of Pastor Mensa Otabil, Bishop Dag Heward-Mills, Archbishop Nicolas DuncanWilliams on how they benefited from the Internet activities 
of the pastors being studied, it was stated that 'the Facebook ministry has broken all geographical barriers and protocols that hitherto hindered preaching and the hearing of the gospel'. They also indicated that the activities of their pastors on Facebook have brought them closer to their churches irrespective of their locations. This phenomenon is described by

Giddens (1991:21-23) as the disembedding of social relationships and organisations. Disembedded relationships allude to the fact that relationships take place in a context where time and space are separated and the interaction is governed by abstract systems (Cloete 2015:3, Hutchings 2011:1118).

This in a nutshell also suggests that any church that spends much on advertising in the traditional media should also consider advertising in social media. The cost of organising a crusade to plant a church in other cities or countries can be achieved through social media if the church uses social media strategically. Bishop Dag Heward-Mills of Lighthouse Chapel International and Bishop Charles Agyin Asare of Perez Chapel International have successfully used this approach for their crusades and church planting activities.

\section{MISSIONAL ACTIVITIES OF GHANAIAN PENTECOSTAL PASTORS ON FACEBOOK}

Being missional is not about what the churches do, but what the churches empower people to do in their everyday lives. The Great Commission is not merely about spreading the gospel in words, it is about embodying the gospel message-its hope for transformational renewal-in our work.

Speaking at the Fresh Expression Conference 2015 in Cape Town, South Africa, Bishop Graham Cray stated that for the church to achieve her missional mandate in the $21^{\text {st }}$ century, it must find new, flexible and appropriate ways to proclaim the gospel afresh to those who do not relate to it in traditional ways. This means that the church must be incarnational in her mission approach. The fundamental importance of mission incarnation is a movement towards where people are, and this calls for an appreciation of the world and the context.

In spite of the fact that some Ghanaian pastors are using Facebook for personal image branding as well as that of their churches, others are also using the same medium for missional purposes. The use of Facebook by some of these pastors is to fulfil in creative ways the Great Commission (Gelfgren 2012: 232).

For example, on the Facebook page of Bishop Charles Agyin Asare of Perez Chapel International in the month of August, were teachings on marriage to celebrate the month he got married ( $30^{\text {th }}$ August). The discussion on his Facebook page painted a picture of Christian marriage and how Christian couples should live. It also went on to paint a picture of the church as the bride of Christ which is being prepared to meet the bridegroom (Christ Jesus).
Archbishop Nicolas Duncan-Williams's teachings and programmes on his Facebook page between June and October, 2015 were on prayer. Through this platform several prayer points regarding prayer for Missionaries were raised. Pastor Mensa Otabil, on the other hand, posted issues on good leadership on his Facebook. Furthermore, messages from Apostle Opuku Onyinah, Chairman of the Church of Pentecost, Bishop Agyen Asare of the Perez Chapel International, and that of Bishop Dag Haward Mills are evangelistic in nature. In addition to the above, the Pastors studied sometimes use their Facebook pages to post videos of their sermons and/or to advertise upcoming events of their churches. In the area of discipleship, some do post daily devotional messages to help their followers with their personal devotion and also to connect to God.

With regard to how some Ghanaian pastors and other ministers of the gospel are making use of the social media, Joubert and Schoeman posit that believers must know that their presence on, and involvement in Facebook, Twitter, Instagram Web pages and other social media can be regarded as a legitimate form of expression of their belief in Christ, which requires the same attention, reflection, planning and prayer as in the case of normal Bible study, cell groups and worship services that form part of congregational life (2015:185).

\section{THE CHURCH AND NEGATIVE USE OF SOCIAL MEDIA}

Having discussed the missional use of facebook by Ghanaian church leaders, it is also very important to discuss the church and the negative use of social media. As social media are usergenerated and empower users to exercise some independence in the access and dissemination of information (Kietzmann et al. 2011), there is a concern within the religious community regarding individualism on social media (Perkins 2012). The concept of individualism on social media makes users prone to people who through these platforms subvert established Christian teachings, doctrines and values (Perkins 2012).

Facebook and its feature of enabling extensive connections among people from different backgrounds, cultures and faiths can serve as a platform for the manipulation of users who use Facebook for religious edification (Perkins 2012). This huge network of people from diverse backgrounds expose users to new habits which can have negative consequences on their behaviour (Rice 2012). Rice asserts that the power and control Facebook places on users create too many choices and links for the user to maintain. On the other hand, the use of inappropriate images, sexual innuendoes and identity theft on Facebook brings about harassment of users and this challenging situation has made some Christian leaders to avoid Facebook (Brachear 2011; Reyes-Chow 2009; Brinton 2010; Badmos 2014).

With the above concerns on the abuse of social media, it is very important that Christians approach social media in a discerning manner. It is therefore essential to understand the impact our status, photos, comments or blog posts may have now and in the future. We should also bear in mind the ramifications of any statement made on social media since everything written is permanent and viewable by everyone. Furthermore, while 
maintaining relationships is important and healthy, addiction is not. Limiting the amount of time we devote to these social networking sites is both healthy and wise.

\section{CONCLUSION}

Using the contemporary introduction of social media, this article made a case for the missional activities of some Ghanaian pastors on Facebook. The article started with an overview of 'cyber church', the concept of social media, the Facebook medium and its potential for mission purposes; and the Facebook usage phenomenon among Ghanaians and Ghanaian Pastors. The study established that among the various social media platforms, Facebook is the leading and the most used platform by Ghanaians. This therefore makes it one of the viable media platforms for the spread of the gospel.

The article argues that being missional is not about what the churches do, but what the churches empower people to do in their everyday lives. The Great Commission is not merely about spreading the gospel in words, it is about embodying the gospel message in an incarnational manner by using new, flexible, and appropriate ways to proclaim the gospel afresh for those who do not relate to it in traditional ways. The fundamental importance of mission incarnation is a movement towards where people are, and this calls for an appreciation of the world and the context. The article concludes that social media and for that matter Facebook is where the people are and those pastors under study are using this platform to propagate the gospel, disciple people in a creative way, interacting with their followers, and helping them to connect to God through their daily devotional posts.

\section{REFERENCES}

Asamoah-Gyadu, J.K. 2007. 'Get on the Internet!' says the Lord: Religion, cyberspace and Christianity in contemporary Africa', Studies in World Christianity, 13(3), 225-242.

Baab, L.M. 2008. 'Portraits of the future Church: A rhetorical analysis of congregational websites, Journal of Communication \& Religion, 31(2), 143-181.

Badmos, K. 2014. Effect of social media on the Church. Paper presented at the 2014 Annual Conference of Theological Friends and Fellows, organized by the Redeemed Christian Bible College Lagos, Nigeria

Baruah, T.D. 2012. 'Effectiveness of Social Media as a tool of communication and its potential for technology enabled connections: A micro-level study', International Journal of Scientific and Research Publications 2(5), 2-3.

Benyah, F. 2015. 'The Use of The Mass Media by Charismatic Churches in Ghana: A Case Study of Perez Chapel International', MPhil thesis, University of Ghana, Legon.

Brachear, M. 2011. Facebook and Christianity a bad mix,

Chicago parish warns. Chicago Tribune. Viewed August 22, 2016 from http://articles.chicagotribune.com/2011-04-06/ news/ct-talk-catholics-facebook-0407-20110406_1_facebookbad-mix-social-network-sites,

Brown, M. 2001. Learn to use Facebook, Twitter and LinkedIn: The How -To Guide, Kindle ed. Vook.

Brinton, H.B. 2010. Are social media changing religion? USA Today. Viewed August 22, 2016 from http://usatoday30. usatoday.com/news/opinion/forum/2010-06-21-column21 ST_N.htm

Campbell, H. \& Calderon, P. 2007. 'The question of Christian community online: The case of the Artist World Network', Studies in World Christianity 13(3), 261-277.

Campbell, H. 2010. When Religion Meets New Media. Routledge, Oxford.

Clark, J. 2012. Facebook for Churches. Church Juice/ Reframe, Palos Heights, Illinois.

Cloete A.L. 2015. 'Living in a digital culture: The need for theological reflection', HTS Teologiese Studies/ Theological Studies 71(2), Art. \#2073, 7 pages, viewed 20 June 2016 from http://dx.doi.org/10.4102/ hts.v71i2.2073.

Constantinides, E. \& Stefan J. Fountain. 2007. 'Web 2.0: Conceptual Foundations and Marketing Issues', Journal of Direct, Data and Digital Marketing Practice 9(3), 232-233.

Desktop social network usage statistics in Ghana, 2015, viewed 20 November 2015 from https://www.statsmonkey. 
com/table/21587-ghana-desktop-social-network-usagestatistics-2015.php.

Downe-Wamboldt, B. 1992. 'Content analysis: Method, applications, and issues', Health Care for Women International, $13,313-321$.

Frobish, T. 2006. 'The virtual Vatican: A case study regarding online ethos', Journal of Communication \& Religion 29(1), 38-69.

Gelfgren, S., 2012, 'Let There Be Digital Networks and God Will Provide Growth? Comparing the Aims and Hopes of 19th-century and Post-millennial Christianity'. In Cheong, P., Fischer-Nielsen, P., Gelfgren, S. \& Ess, C., eds. Digital Religion, Social Media and Culture: Perspectives, Practices, Futures, 227-242, Peter Lang, New York.

Ghana Social Media Usage Statistics Using Mobile, 2015, viewed 20 August 2015 from https://www.statsmonkey. com/sunburst/21354-ghana-mobile-social-media-usagestatistics-2015.php.

Ghana Statistical Service, 2012, Population \& Housing Census 2010, Sakofa Press Limited, Accra.

Giddens, A. 1991. Modernity and self-identity: Self and society in the late modern age, Stanford University Press, Stanford.

Gould, M. 2013. The Social Media Gospel: Sharing the good news in a new way, Liturgical Press, Collegeville, Minnesota.

Heidi, A. \& Campbell, H.A. 2012. Understanding the Relationship between Religion Online and Offline in a Networked Society, Journal of the American Academy of Religion 80 (1), 64-93.

Helland, C. 2005. 'Online religion as lived religion: Methodological issues in the study of religious participation on the Internet', Heidelberg Journal of Religions on the Internet 1(1), 1-15.

Horsfall, S. 2000. How religious organizations use the Internet: A preliminary inquiry. In D. Cowan, \& J. Hadden (Eds.), Religion on the Internet: Research prospects and promises, pp. 153-162, JAI Press, London.

Huchings, T. 2011. 'Creating church online a case-study approach to religious experience', Studies in World Christianity 13(3), 1118-1131, viewed 20 June 2016 from http://dx.doi. org/10.3366/swc.2007.13.3.243.

Hutchings, T. 2011. 'Contemporary Religious Community and the Online Church', Information, Communication \& Society 14(8), 1118-1135.

Internet World Statistics, 2015, viewed 20 November 2015 from http://www.internetworldstats. com/stats1.htm.

Joubert, S. \& Schoeman, W.J. 2015. An exploration of the use of technology, Acta Theologica Supplementum 22, 185.
Kasule, M.R. 2013. Increase of Internet usage in Ghana and Its Implications, viewed 7 June 2015 from http://www.ghanaweb. com/GhanaHomePage/NewsArchive/artikel.php?ID=286132.

Kietzmann, J.H., Hermkens, K., McCarthy, I.P., \& Silvestre, B.S. 2011. Social media? Get serious! Understanding the functional building blocks of social media. Business Horizons, 54(3):241251.

Knowles, S. 2013. 'Rapture Ready and the World Wide Web: Religious Authority on the Internet', Journal of Media and Religion 12(3), 128-143.

Kondracki, N. L. \& Wellman, N.S. 2002. 'Content analysis: Review of methods and their applications in nutrition education', Journal of Nutrition Education and Behavior, 34, 224230.

Mayfield, A. 2008. What is social media? Viewed 29 February 2016 from, http://www.icrossing.com/uk/sites/default/ files_uk/insight_pdffiles/What\%20is\%20Social\%20Media_ iCrossing_ebook.pdf.

Nadella, R. 2013. 'Redefining Connectedness', in Theological Investigations in the Church and Culture, Columbia Theological Seminary, Columbia.

Neuendorf, K.A. 2002. The Content Analysis Guidebook, Sage Publications, California.

Niemandt, C.J.P. 2013. 'A network society, social media, migration and mission', Missionalia, 41(1), 30.

Perkins, P.W. 2012. The manifestation of biblical community understanding in a Facebook community: A qualitative study among Christian College students. Doctorate dissertation. Liberty University: Lynchburg, VA.

Pew Internet and American Life Project, 2000, Wired churches, wired temples: Taking congregations and missions into cyberspace, viewed 31 March 2016 from http://www.pewinternet. org/files/old-media/Files/Reports/200o/PIP_Religion_Report. pdf.pdf

Reyes-Chow, B. 2009. Top three ways you know technology is killing your Church [Web log post]. Retrieved August 22, 2016 from http://reyes-chow.com/2009/03/top-10ways-technologycan-kill-the-church/

Rice, J. 2009. The church of Facebook. Colorado Springs, CO: David C. Cook.

Social Ecclesia: Spirit-Led Digital Presence, 2014, viewed 29 February 2016 from http://www.christianitytoday.com/ edstetzer/2014/january/social-ecclesia-spirit-led-digitalpresence.html.

Socialbakers, 2015. Mensa Otabil Facebook statistics, 
viewed 20 August 2015 from http://www.socialbakers.com/ statistics/Facebook/pages/detail/130834395116-mensa-otabil.

Socialbakers.2015.Ghana Facebook Page Statistics, viewed 20

August 2015 from http://www.socialbakers.com/statistics/ facebook/pages/total/ghana.

Sturgill, A. 2004. 'Scope and purposes of church web sites', Journal of Media \& Religion, 3(3), 165-176.

Susan Codone, S. 2014. 'Mega church Pastor Twitter Activity: An Analysis of Rick Warren and Andy Stanley, two of America's Social Pastors', Journal of Religion, Media and Digital Culture, 3(2), 3.

Sweet, L. 2012. Viral: How social Networking is poised to ignite revival, Waterbrook Press, Colorado.

Vosko, R. 2011. 'Liturgical Technology, Social Media, and the Green Church', Liturgical Ministry (Spring), 91.

Wellman, B. \& Haythornthwaite, C. (Eds.) 2002. The Internet and everyday life, Blackwell, Oxford.

White, P. \& Niemandt, C.J.P. 2015. 'Ghanaian Pentecostal Churches' Mission Approaches', Journal of Pentecostal Theology 24(2), 241-269.

White, P. 2014. A missiological study of the role of the baptism and infilling of the Holy Spirit in Ghanaian Pentecostal churches, $\mathrm{PhD}$ Thesis submitted to the University of Pretoria, Faculty of Theology, Department of Science of Religion and Missiology.

Wise, J. 2014. 'Social Media and Christian Ministry: Reaching the World for the Kingdom of God', viewed 16 March 2016 from http://www.christianitytoday.com/edstetzer/2014/ february/ social-media-and-christian-ministry-reaching-world-for-king. html.

Wise, J. 2014. The Social church: A Theology of Digital Communication, Moody Publishers, Chicago. 